\title{
The concept of hard coal mine \\ in the perspective of Industry 4.0
}

doi:10.2478/mape-2019-0032

Date of submission to the Editor: 06/2018

Date of acceptance by the Editor: 07/2018

MAPE 2019, volume 2, issue 1, pp. 327-335

\section{Dorota Palka*}

ORCID ID: 0000-0002-1441-4197

Silesian University of Technology, Poland

\section{Tamer Rizaoğlu}

ORCID ID: 0000-0002-4883-0842

Kahramanmaras Sütçü İmam University, Kahramanmaras, Turkey

\section{INTRODUCTION}

The strategic goal for 2020 in modern Europe is to implement three main priorities. One of them is investing in intelligent industry development, based on knowledge and innovation. The proposed strategy is a factor in improving the economy of EU countries while maintaining the principles of sustainable development. The designated course of action includes economic and social development, technical progress as well as improvement of the political sphere, health, consumption and knowledge. Innovative activities undertaken in the manufacturing and production industry should lead to minimization of production costs, improvement of product quality, increase of work efficiency with simultaneous improvement of organization and work safety as well as protection of the natural environment (Bluszcz, 2016).

In Poland, the need to undertake innovative activities should be directed at mining industry enterprises. Coal is the basic raw material for electricity and heat production, guaranteeing energy security. In terms of annual production, Poland ranks tenth in the global rankings and first place in the European Union. In addition, coal mining provides employment to nearly 180000 people. Despite numerous changes in the structure of mining plants, mining restructuring, automation of exploitation processes, underground mining is the only source of income for thousands of families in this region. For this reason, it is very important to take all kinds of actions to ensure the efficiency of this industry (Brodny, Tutak, 2018; Brodny, Tutak, 2019). Working in underground mining plants is extremely difficult and dangerous due to the complex and unpredictable environment. The coal exploitation process is inseparably connected with both natural and technical hazards. The accumulation of negative factors such as: dangerous gases, methane, high temperature, noise, the risk of rock ejection is a threat to the crew and equipment of mining excavations (Palka, Stecuła, 2019; Stecuła, Brodny, Tutak, 2017)

The history of underground mining has been and continues to be the scene of hundreds of fatal accidents in various parts of the world. One of the most important example of this is Soma Eynez mining quarry disaster from the western Turkey

\footnotetext{
‘ dorota.palka@polsl.pl
} 
occurred in 2014 due to a fire in the underground coal mine and caused 301 fatalities that accounts for almost half of the death of the last 30 years (Akgün, 2015; Düzgün \& Leveson, 2018). In the history of mining, very primitive methods have been used in the detection of hazardous gases which are potential hazards. In order to detect any gas leakage, the birds in the cage were left in the mines and the effect of the gases on them was observed but, nowadays, those gases can be detected earlier by using advanced technological facilities in these areas (Akgün, 2015). In addition, underground mining exploitation has a very negative impact on the external environment, including the natural environment, as well as on the infrastructure located on the surface. In many cases, these are all kinds of deformations on the surface are known as mining damage caused successively: collapse of the ceiling into the post-mining void, deflection or cracking of rock layers, geological or hydrogeological changes, deformations of the mining area, causing damage, buildings, water supply, thermal and power. In order to ensure safety and comfort of work, reducing the negative impact of mining on the environment and maintaining operational efficiency, it is necessary to apply modern technology, in particular advanced machines and devices. An example of such an approach is the implementation of solutions proposed in the concept of the fourth industrial revolution. These solutions are an opportunity to improve coal exploitation processes, use of IT tools supporting decision-making processes and ensuring real-time process management. However, the specificity of the mining environment poses many barriers (Palka, Brodny, Rizaoglu, Bagci, Mascenik, 2018, Palka, Brodny, Stecuła, 2017).

\section{STATE OF MINING IN POLAND}

Determining the directions of development of underground coal mining technology requires knowledge of the current state of mining. An important factor in this respect are, among others, geological conditions. The thickness of hard coal deposits in Poland ranges from several dozen centimeters to over twenty meters. The coal is exploited for deposits with a thickness of more than 1.5 meters. Most of the decks are inclined at an angle of less than $35^{\circ}$, which allows for use with a longwall system. Among numerous irregularities in the deposit of hard coal deposits, the most frequent and most troublesome deposits are sedimentary and tectonic accidents. The faults often mark the boundaries of mining areas, decks and exploitation fields and operation parameters. The occurrence of faults causes a change in geodynamic stresses, including rock bursts and bumps. Mining activities can trigger the seismic activity as well (Orlecka-Sikora et al 2009). Continuous extraction of resources means that exploitation takes place deeper and deeper. Current depths reach up to 1200 meters underground. Increasing the depth of exploitation causes an increase in stresses in the rock mass, an increase in the temperature, an increase in the strength of rocks surrounding the seams and an increase in methane. In over $50 \%$ of mines, exploitation is carried out in the IV (highest) category of methane hazard. These changes are a threat to shocks, bumps, fires and gas explosions. The most common natural threat in Polish mining is the fire hazard. This applies to all mines due to the irreversible absorption of coal for auto-ignition, as well as the numerous factors that intensify these threats. Increasing the depth of exploitation means that mining robot operation will become very dangerous. In particular, this also applies to mining enclosures which must meet increasingly higher technical requirements in order to 
protect mine working (Drenda, 2013, Szurgacz, Brodny; 2019, Brodny, 2010). Working conditions in Polish underground mining are very difficult and uncomfortable. As the depth increases, the temperature of the rock mass, which under certain conditions is close to $45^{\circ} \mathrm{C}$. The air temperature in underground mining excavations may then exceed $30^{\circ} \mathrm{C}$. Unfavorable climatic conditions worsen the presence of mining machines, because they are an additional source of heat. In addition, the operating process machines are a source of annoying noise and dust pollution. It is worth noting that in underground mining, acoustic effects are additionally strengthened by sound reflections from the surface of mining excavations. In underground excavations during operation, the noise level often reaches dangerous values, in particular during blasting works. Mining machines and used equipment are the source of technical hazards and frequent accidents. In order to understand the unpleasantness of working in mining conditions, it is worth imagining very low excavations that prevent the figure from being straightened, the air humidity in the range from $80 \%$ to even $100 \%$ and the darkness making it impossible to see your own hand (Drenda, 2013).

Exploitation of hard coal causes unfavorable changes in the natural environment. It causes surface deformation, hydrological changes, production and storage of waste and gangue, pollution of water and air. It is also worth noting that hard coal mining in Poland takes place directly under heavily built-up areas, cities, housing estates and roads. Underground mining exploitation causes the formation of voids in the rock mass, which are filled up as a result of gravity. In operation with a roof failure, the rocks located directly above the selected space undergo refraction and fill the void. Mining terrain deformations cause damage to buildings. They can undergo both structural elements and elements of finishing and equipment. There are scratches or cracks in foundations, walls and ceilings. Cracks of roofs, chimneys, sewage systems, water installations are observed, including especially dangerous gas installations. Damage to the finishing elements most often pose a threat to the safety of buildings, and they are to be burdensome for users. The deflection of the building from the vertical causes the lowering of the level of functional properties, connected for example with the loss of stability of the furniture, automatic opening of doors and windows, disturbances in the operation of central heating. A further consequence of damage of this type is often the dampness of the walls caused by the change of gutter falls. In addition, mining exploitation negatively affects the condition of the soil and vegetation (Zorychta, Burtan, 2008).

Every mining operation causes unfavorable changes in the environment, both underground and external. Eliminating them is often impossible, but action should be taken to limit them as much as possible. One of the proposed activities is the implementation of modern technology of the 4.0 industry concept.

\section{THE CONCEPT OF MINE 4.0}

The Idea of Industry Concept 4.0 refers to the fourth industrial revolution. This revolution involves the integration of systems and the creation of networks connecting people with machines. It means the unification of the real world of machines and the virtual world of the Internet. The fourth industrial revolution allows access to any information at any time, from anywhere. Thanks to this, it will be possible to further deepen automation, continuous optimization of products and processes, collection 
and processing of a large number of data in real time, preventive maintenance of machinery and equipment, as well as rapid adaptation to changes in the market situation. The fourth industrial revolution is possible thanks to the development of new technologies. Enterprises implementing the modern concept gain maximum flexibility and a significant advantage over the competition (Ślusarczyk, 2018).

Technological solutions that give the opportunity to implement the concept of industry 4.0 are: autonomous robots, simulation and forecasting techniques, vertical and horizontal integration, industrial Internet of Things or direct communication between the machine, innovative methods of collecting and processing huge amounts of data - Big Data, including the use of potential activities in the cloud (Clouds), additive technologies, technologies of augmented reality and virtual reality, cyber-physical systems such as digital twins using Artificial Intelligence and neural networks and broadly understood Cybersecurity. These issues are often referred to as the pillars of the fourth industrial revolution (Jurdziak, Błażej, Bajda, 2018), (Ślusarczyk, 2018). This paper proposes the use of example solutions of the concept 4.0 for underground hard coal mining. Proposals for solutions are included in Table 1.

\section{Table 1}

The concept of mine 4.0

\begin{tabular}{|c|c|c|c|}
\hline SOLUTION & $\begin{array}{c}\text { AREA } \\
\text { OF APPLICATION }\end{array}$ & DISADVANTAGES & ADVANTAGES \\
\hline $\begin{array}{l}\text { Autonomous } \\
\text { machines } \\
\text { (longwall } \\
\text { complexes) }\end{array}$ & $\begin{array}{l}\text { mining of coal, protection } \\
\text { of the roof, crushing } \\
\text { of rocks, transportation } \\
\text { of spoil, safety }\end{array}$ & $\begin{array}{l}\text { high implementation } \\
\text { costs, reduction of } \\
\text { employment, demand } \\
\text { for specialized staff }\end{array}$ & $\begin{array}{c}\text { safe operation, reduced } \\
\text { accidental costs, increased } \\
\text { efficiency }\end{array}$ \\
\hline $\begin{array}{l}\text { Monitoring } \\
\text { machines } \\
\text { in real time }\end{array}$ & $\begin{array}{l}\text { mining machines } \\
\text { and equipment }\end{array}$ & $\begin{array}{l}\text { high implementation } \\
\text { costs, an indispensable } \\
\text { qualified employee }\end{array}$ & $\begin{array}{l}\text { possibility of quick reaction, } \\
\text { carrying out preventive } \\
\text { actions, ensuring traffic } \\
\text { maintenance and continuity } \\
\text { of traffic, work control }\end{array}$ \\
\hline Big Date & $\begin{array}{c}\text { machine operation } \\
\text { parameters } \\
\text { and equipment, mining } \\
\text { level data, transport } \\
\text { and coal processing data }\end{array}$ & $\begin{array}{l}\text { huge amount of } \\
\text { processed data, the } \\
\text { need for advanced } \\
\text { analytical tools, } \\
\text { advanced interface, } \\
\text { maintenance costs }\end{array}$ & $\begin{array}{l}\text { ongoing monitoring } \\
\text { of parameters in real time, } \\
\text { improvement of work } \\
\text { organization, the possibility } \\
\text { of undertaking preventive } \\
\text { actions }\end{array}$ \\
\hline Data cloud & $\begin{array}{l}\text { digital systems regarding } \\
\text { selected mining } \\
\text { parameters }\end{array}$ & $\begin{array}{l}\text { cyber attacks, control } \\
\text { against data loss, } \\
\text { advanced data } \\
\text { protection, IT support } \\
\text { needed, high } \\
\text { maintenance costs }\end{array}$ & $\begin{array}{c}\text { possibility of remote } \\
\text { cooperation of mining } \\
\text { company departments, } \\
\text { systematized data, open } \\
\text { access to data }\end{array}$ \\
\hline $\begin{array}{l}\text { Autonomous } \\
\text { gas meters }\end{array}$ & $\begin{array}{c}\text { security, } \\
\text { data collection }\end{array}$ & $\begin{array}{c}\text { disturbances in } \\
\text { measurements, high } \\
\text { maintenance costs, } \\
\text { difficult implementation } \\
\text { conditions, technical } \\
\text { limitations }\end{array}$ & $\begin{array}{l}\text { precise measurement, } \\
\text { constant monitoring of gas } \\
\text { levels, possibility of predicting } \\
\text { mining events, reliable data }\end{array}$ \\
\hline $\begin{array}{l}\text { Integrated } \\
\text { dispatcher } \\
\text { system }\end{array}$ & connectivity and alarming & $\begin{array}{l}\text { high costs, technical } \\
\text { limitations, the need for } \\
\text { fitness checks }\end{array}$ & $\begin{array}{l}\text { wireless connectivity, speed } \\
\text { of information transfer, } \\
\text { immediate reaction possible }\end{array}$ \\
\hline $\begin{array}{l}\text { Chips } \\
\text { identifying } \\
\text { employees }\end{array}$ & monitoring employees & $\begin{array}{l}\text { high implementation } \\
\text { costs, large surveillance } \\
\text { in the employees' rights, } \\
\text { lack of staff acceptance, } \\
\text { an enormous database }\end{array}$ & $\begin{array}{l}\text { work safety, faster } \\
\text { identification of employees, } \\
\text { constant supervision of work }\end{array}$ \\
\hline
\end{tabular}


Table 1 (continued)

The concept of mine 4.0

\begin{tabular}{|c|c|c|c|}
\hline $\begin{array}{l}\text { Integration } \\
\text { system } \\
\text { belt } \\
\text { conveyors } \\
\text { DiagBelt }\end{array}$ & transport & $\begin{array}{l}\text { high purchase costs, } \\
\text { qualified staff }\end{array}$ & $\begin{array}{l}\text { information on the quantity } \\
\text { and quality of transported } \\
\text { spoil, current object } \\
\text { diagnostics, alarm and } \\
\text { warning systems, reduction } \\
\text { of failure rate, remote work }\end{array}$ \\
\hline $\begin{array}{l}\text { Innovative } \\
\text { modeling } \\
\text { software }\end{array}$ & virtual deposit modeling & $\begin{array}{l}\text { qualified staff, } \\
\text { reorganization of the } \\
\text { work of surveying } \\
\text { departments, the need } \\
\text { for additional } \\
\text { measurements }\end{array}$ & $\begin{array}{l}\text { refinement and modernization } \\
\text { of documentation, precise } \\
\text { geological information, the } \\
\text { possibility of remote } \\
\text { cooperation between mine } \\
\text { departments }\end{array}$ \\
\hline $\begin{array}{l}\text { 3D scanning } \\
\text { system }\end{array}$ & $\begin{array}{l}\text { blasting and drilling works } \\
\text { (designing the grid } \\
\text { of blast holes) }\end{array}$ & $\begin{array}{l}\text { high equipment costs, } \\
\text { organizational work } \\
\text { changes, need for } \\
\text { additional training, } \\
\text { advanced interface }\end{array}$ & $\begin{array}{l}\text { safety, improvement of the } \\
\text { efficiency of drilling and } \\
\text { blasting works, reduction } \\
\text { of material consumption, } \\
\text { task optimization }\end{array}$ \\
\hline GIS System & $\begin{array}{l}\text { Digital mapping } \\
\text { of a mining company }\end{array}$ & $\begin{array}{l}\text { the need to acquire and } \\
\text { process and analyze a } \\
\text { large amount of data, } \\
\text { high implementation and } \\
\text { maintenance costs, the } \\
\text { need to create additional } \\
\text { workplaces for GIS } \\
\text { specialists, } \\
\text { cyber attacks }\end{array}$ & $\begin{array}{l}\text { connection of various areas of } \\
\text { mining activity, transparency } \\
\text { and legibility of mining } \\
\text { documentation, conversion of } \\
\text { analogue documents into } \\
\text { digital documents, possibility } \\
\text { of cooperation, current data }\end{array}$ \\
\hline Virtual reality & $\begin{array}{l}\text { Mining and health } \\
\text { and safety trainings }\end{array}$ & $\begin{array}{l}\text { high costs, limited } \\
\text { equipment resources, } \\
\text { reorganization of the } \\
\text { training department's } \\
\text { work }\end{array}$ & $\begin{array}{l}\text { modern way of conducting } \\
\text { trainings, implementation } \\
\text { of the prevailing mine } \\
\text { conditions, the possibility } \\
\text { of preparing the employee } \\
\text { for emergency situations }\end{array}$ \\
\hline $\begin{array}{l}\text { Augmented } \\
\text { reality }\end{array}$ & $\begin{array}{c}\text { Workplace training, } \\
\text { vocational training, service } \\
\text { and maintenance of } \\
\text { machines, } \\
\text { maintenance }\end{array}$ & $\begin{array}{l}\text { high costs, limited } \\
\text { equipment resources, } \\
\text { technical limitations, } \\
\text { staff resistance, the } \\
\text { need to improve staff } \\
\text { qualifications }\end{array}$ & $\begin{array}{l}\text { modern way of conducting } \\
\text { trainings, limiting human } \\
\text { error, automatic work control, } \\
\text { help for an employee }\end{array}$ \\
\hline Cybersecurity & digital systems & $\begin{array}{l}\text { the need for constant } \\
\text { updating, IT specialists, } \\
\text { high maintenance costs, } \\
\text { phishing threats, } \\
\text { ransomware }\end{array}$ & $\begin{array}{l}\text { data protection, control } \\
\text { and supervision over the } \\
\text { automation of mining } \\
\text { processes, remote assistance } \\
\text { and control }\end{array}$ \\
\hline Digital mine & $\begin{array}{l}\text { Interdisciplinary } \\
\text { application }\end{array}$ & $\begin{array}{c}\text { qualified staff, high } \\
\text { implementation costs, } \\
\text { the need to analyze a } \\
\text { large amount of data, } \\
\text { the need to integrate } \\
\text { systems }\end{array}$ & $\begin{array}{l}\text { increase of competitiveness } \\
\text { and management efficiency } \\
\text { of mining production, } \\
\text { reduction of production costs, } \\
\text { ensuring security, increase } \\
\text { of work efficiency, possibility } \\
\text { of cooperation with semi- } \\
\text { mining companies }\end{array}$ \\
\hline
\end{tabular}

Source: Own elaboration based on (Stadnicka, Zielecki, Sęp, 2017, Wittbrodt, Łapuńka, 2017).

The suggested solutions of the concept 4.0 presented in the table are examples referring to the pillars of the fourth revolution. They were selected on the basis of a literature review. As a result of the research and conversations, the advantages and disadvantages of the proposed solutions were developed. Among the most repetitive 
advantages are: improvement of work efficiency, safety and integration of mining company departments. Among the disadvantages, there are often high costs, limitations resulting from the specificity of the mining environment and the need for qualified staff.

When assessing the feasibility of implementing the proposed ideas, it is worth obtaining answers to the questions prepared and listed in Table 2.

Table 2

Questions analyzing the possibility of implementing the concept

\begin{tabular}{|c|c|}
\hline $\begin{array}{c}\text { Autonomous } \\
\text { machines } \\
\text { (longwall complexes), } \\
\text { Autonomous } \\
\text { gas meters }\end{array}$ & $\begin{array}{c}\text { Are there automated / autonomous machines and technological devices } \\
\text { in the company? Does the company see the need to implement } \\
\text { autonomous machines cooperating with the operator? } \\
\text { What are the obstacles/restrictions? }\end{array}$ \\
\hline $\begin{array}{c}\text { Monitoring } \\
\text { machines in real time, } \\
\text { Integration system } \\
\text { belt conveyors } \\
\text { DiagBelt }\end{array}$ & $\begin{array}{l}\text { Are the sensors that collect information in real time used in the process? } \\
\text { What information is available in the system? Whether sensor systems } \\
\text { and programs that perform automatic evaluation, eg information about } \\
\text { the state of the machine (noise, vibration, temperature of treatment fluids.) } \\
\text { Are the organizations servicing the machines in the company monitoring } \\
\text { them remotely? In which areas would it be worth implementing } \\
\text { the sensors to collect data on an ongoing basis? }\end{array}$ \\
\hline Big Date & $\begin{array}{c}\text { Are the data of the completed processes being collected on a regular basis } \\
\text { in the databases? Are these data used for making decisions in real time? Is } \\
\text { the data archived? In what form are they collected and how they are } \\
\text { analyzed? What is the big data application? }\end{array}$ \\
\hline $\begin{array}{l}\text { Integrated dispatcher } \\
\text { system, GIS System, } \\
\text { Digital mine }\end{array}$ & $\begin{array}{l}\text { What computer systems are used in the enterprise? Are these systems } \\
\text { interconnected? Is the data freely transferred between systems? What are } \\
\text { the limitations of the implementation options? }\end{array}$ \\
\hline $\begin{array}{l}\text { Chips identifying } \\
\text { employees }\end{array}$ & $\begin{array}{l}\text { Is it possible to integrate sensors with the enterprise system? What are the } \\
\text { restrictions? }\end{array}$ \\
\hline $\begin{array}{l}\text { Innovative } \\
\text { modeling software, } \\
\text { 3D scanning system }\end{array}$ & $\begin{array}{l}\text { Is 3D modeling performed in the company? For what purpose? Do you use } \\
\text { 3D scanning? What are the restrictions? What resources does the company } \\
\text { have? }\end{array}$ \\
\hline $\begin{array}{l}\text { Virtual and } \\
\text { Augmented reality }\end{array}$ & $\begin{array}{l}\text { Does the mining company use virtual and augmented reality? For what } \\
\text { purpose? What application? What limitations? }\end{array}$ \\
\hline Cybersecurity & $\begin{array}{c}\text { Are there special safeguards for data stored in databases and systems } \\
\text { against cyber attacks? Does the company consider cyber attacks to be } \\
\text { a real threat? Are copies of data created on an ongoing basis? Are only } \\
\text { standard safeguards used? }\end{array}$ \\
\hline
\end{tabular}

Source: Own elaboration based on (Stadnicka, Zielecki, Sęp, 2017, Wittbrodt, Łapuńka, 2017).

\section{ANALYSIS}

On the basis of literature, technical documents and review of the proposed questions, an analysis of the possibilities of implementing modern solutions was carried out. The analysis is presented in the table below, Table 3 . 
Table 3

\section{Analysis of the possibility of compromising the proposed solutions}

\begin{tabular}{|c|c|}
\hline SOLUTIONS & ANALYSIS \\
\hline $\begin{array}{l}\text { Autonomous machines } \\
\text { (longwall complexes) }\end{array}$ & $\begin{array}{l}\text { Lack of implementation: specificity of the Polish mining environment, } \\
\text { geological and technical limitations, too high implementation costs, lack of } \\
\text { qualified staff. }\end{array}$ \\
\hline $\begin{array}{l}\text { Monitoring } \\
\text { machines in real time }\end{array}$ & $\begin{array}{l}\text { Partially implemented: there are developed systems and first } \\
\text { implementations, there are many scientific and technical studies, } \\
\text { the need to improve the qualifications of the staff. }\end{array}$ \\
\hline Big Date & $\begin{array}{l}\text { Partially implemented: along with monitoring the work of machines, huge } \\
\text { databases collecting and processing data are implemented. }\end{array}$ \\
\hline Data cloud & It is possible to implement: now partially use external servers. \\
\hline $\begin{array}{l}\text { Autonomous } \\
\text { gas meters }\end{array}$ & $\begin{array}{l}\text { Lack of implementation: the specificity of the Polish mining environment, } \\
\text { excessive dustiness, technical limitations. }\end{array}$ \\
\hline $\begin{array}{l}\text { Integrated dispatcher } \\
\text { system }\end{array}$ & $\begin{array}{l}\text { It is possible to implement: the dispatcher's position has been partially } \\
\text { modernized, technical limitations, communication and data transfer } \\
\text { restrictions. }\end{array}$ \\
\hline $\begin{array}{l}\text { Chips identifying } \\
\text { employees }\end{array}$ & $\begin{array}{l}\text { It is possible to implement: a system was developed to implement } \\
\text { the solution, technically feasible, negative employee reception, high } \\
\text { implementation costs. }\end{array}$ \\
\hline $\begin{array}{l}\text { Integration system } \\
\text { belt conveyors DiagBelt }\end{array}$ & $\begin{array}{l}\text { Lack of implementation: there are numerous scientific and technical } \\
\text { studies, tests and analyzes are underway, too high costs, technical } \\
\text { and mining constraints resulting from environmental conditions. }\end{array}$ \\
\hline $\begin{array}{l}\text { Innovative } \\
\text { modeling software }\end{array}$ & $\begin{array}{l}\text { It is possible to implement: partly use modern programs, promotional } \\
\text { applications for the needs of training or presentation, the barrier } \\
\text { of the traditional approach of the staff and the specifics of work in mining. }\end{array}$ \\
\hline 3D scanning system & $\begin{array}{c}\text { Lack of implementation: very high costs, technical and geological } \\
\text { constraints, the need to qualify staff, reorganize work, limited resources, } \\
\text { there are numerous research and scientific studies. }\end{array}$ \\
\hline GIS System & $\begin{array}{l}\text { It is possible to implement / partially implemented: implementation works } \\
\text { are underway, there are numerous studies currently mainly promotional } \\
\text { and training, high costs, the need to create new jobs } \\
\text { and employment of specialists. }\end{array}$ \\
\hline $\begin{array}{l}\text { Virtual reality and } \\
\text { Augmented reality }\end{array}$ & $\begin{array}{l}\text { It is possible to implement / partially implemented: part } \\
\text { of the proposed solution is used, financial constraints and resources. }\end{array}$ \\
\hline Cybersecurity & Inability to implement: very high implementation and maintenance costs. \\
\hline Digital mine & $\begin{array}{l}\text { Partially implemented: there are developed and integrated systems, } \\
\text { limitations resulting from the lack of data and integration of mining } \\
\text { company departments }\end{array}$ \\
\hline
\end{tabular}

\section{CONCLUSION}

The aim of the article was to bring the idea of the fourth industrial revolution closer to the needs of the Polish hard coal mining industry. The study presents examples of Industry 4.0. Their application areas as well as advantages and disadvantages of implementation were discussed. On the basis of the conducted research, the possibilities of implementing the proposed solutions were analyzed. The analysis shows that some of the proposed solutions already exist in mining. Usually, these solutions are implemented only partially due to costs or other restrictions. The lack of implementation option concerns the current state of mining. It is anticipated that with the advancement of technology, current barriers will be possible to solve. This way, the main elements of the necessary changes in the mining enterprise are discussed. It also indicates the direction of mining technology progress and development opportunities. The indicated limitations and barriers may form the basis for the research in this area.

In Poland, coal is the basic energy resource, along with depletion of coal resources, exploitation is carried out on ever deeper decks. With increasing depth, mining is 
becoming more and more dangerous. Therefore, investing in modern systems that ensure safe and effective work is necessary. However, the financial situation of Polish mining is unfavorable and is a common barrier.

An interesting issue seems to be the human factor, which many times appeared in the analysis. Modern technical solutions reduce the need for employees performing routine physical tasks, while the demand for specialists in the IT area will increase. Modern systems, as well as machines and devices requiring very advanced knowledge to operate and use them, as well as programming, data analysis, designing solutions and IT interfaces, appear in enterprises. These changes force the development of new staff competences. In the human-machine-environment system, it will be possible to achieve full integration, which will significantly affect the way the work is done and organizational structures in the enterprise. However, the lack of proper preparation of staff, training and organization may pose a significant threat to the expansion of modern technologies.

This article can be used as a voice in a scientific discussion. The developed recommendations may indicate the further direction of research and technology development.

\section{ACKNOWLEDGEMENTS}

This article is the result of research conducted at the Institute of Production Engineering, Faculty of Organization and Management, Silesian University of Technology, within the statutory work entitled "Research into the possibility of implementing the concept of the Industry 4.0 in industrial enterprises." (nr BKM510/ROZ3/2019).

\section{REFEENCES}

Akgün, M. (2015). Coal mine accidents. Turkish thoracic journal, 16(Suppl 1), S1.

Bluszcz, A. (2016). Classification of the European Union member states according to the relative level of sustainable development, Quality \& Quantity 50.6, pp. 2591-2605.

Brodny, J. and Tutak M. (2019). Analysis of the diversity in emissions of selected gaseous and particulate pollutants in the European Union countries. Journal of Environmental Management, 231, pp. 582-595, DOI 10.1016/j.jenvman.2018.10.045

Brodny, J. and Tutak, M. (2018). Exposure to harmful dusts on fully powered longwall coal mines in Poland. International Journal of Environmental Research and Public Health, 15(9), pp. 1-16. DOI 10.3390/ijerph15091846

Brodny, J. (2010). Determining the working characteristic of a friction joint in a yielding support. Archives Min. Sci., 55(4), pp. 733-746.

Drenda, J. (2013). Klimat w przodkach ścianowych i przodkach wyrobisk korytarzowych śląskich kopalń węgla - stan w 2012 roku. Materiały XXII Szkoły Eksploatacji Podziemnej.

Düzgün, H. Sebnem. and Nancy L. (2018). Analysis of soma mine disaster using causal analysis based on systems theory (CAST)." Safety science 110, pp. 37-57.

Jurdziak, L., Błażej, R. and Bajda M. (2018). Cyfrowa rewolucja w transporcie przenośnikowym - taśma przenośnikowa 4.0. Transport, 2, pp. 40.

Orlecka-Sikora, B., Papadimitriou, E. E. and Kwiatek, G. (2009). A study of the interaction among mining-induced seismic events in the Legnica-Głogów Copper District, Poland. Acta Geophysica, 57(2), pp. 413-434.

Palka, D., Brodny, J., Rizaoglu, T., Bagci, U. and Mascenik J. (2018). Literature research in the field of Technology Assessment using a tool of a Systematic Literature Review, XV International Conference Multidisciplinary Aspects of Production Engineering, MAPE, 1(1), pp. 109-115. 
Palka, D., Brodny, J. and Stecuła, K. (2017). Modern means of production and the staff awareness of the technical in the plant of the mining industry. CBU International Conference Proceedings, Praha: Central Bohemia University, pp. 1190-1194. DOI 10.12955/cbup.v5.1094

Palka, D., Stecula, K., ( 2019). Concept of technology assessment in coal mining. IOP Conf. Series: Earth and Environmental Science, 261, pp. 1-8, doi:10.1088/1755$1315 / 261 / 1 / 012038$

Stadnicka, D., Zielecki, W. and Sęp, J. (2017). Koncepcja Przemysł 4.0 - ocena możliwości wdrożenia na przykładzie wybranego przedsiębiorstwa, Innowacje w Zarządzaniu i Inżynierii Produkcji, 1, pp. 472-483.

Stecuła, K., Brodny, J. and Tutak M. (2017). Informatics platform as a tool supporting research regarding the effectiveness of the mining machines' work. In: CBU International Conference Proceedings, Innovations in Science and Education, 5, pp. 1215-1219. DOI 10.12955/cbup.v5.1099

Szurgacz, D. and Brodny, J. (2019). Analysis of the influence of dynamic load on the work parameters of a powered roof support's hydraulic leg. Sustainability. MPDI. Sustainability, 11, pp. 2570. doi:10.3390/su11092570

Ślusarczyk, B. (2018). Industry 4.0: are we ready?. Polish Journal of Management Studies, 17.

Wittbrodt, P. and Łapuńka, I. (2017). „Przemysł 4.0 - Wyzwanie dla Współczesnych Przedsiębiorstw Produkcyjnych". Innowacje w Zarządzaniu i Inżynierii Produkcji, 2, pp.793-799.

Zorychta, A. and Burtan, Z. (2008). Uwarunkowania i kierunki rozwoju technologii podziemnej eksploatacji złóż w polskim górnictwie węgla kamiennego. Gospodarka Surowcami Mineralnymi, 24(1/2), pp. 53-70.

\begin{abstract}
For the Polish economy, hard coal is the basic raw material for the production of electricity and heat, guaranteeing energy security. To ensure safe and effective work in underground mines, the most modern technical solutions are implemented. Innovative achievements of production automation are increasingly being used. Introduction of the Industry 4.0 concept elements is an opportunity for: improvement of coal exploitation processes, use of IT tools supporting decisionmaking processes and ensuring real-time process management. However, the specificity of the mining environment poses many barriers, for example limitations resulting from geology, extent and volume of excavations, device mobility and telecommunications. The article describes mining threats and limitations as well as the current technical condition of Polish mining. The latest trends in mining development are described in line with the ideas of the fourth industrial revolution. The main goal of the article is to analyze the feasibility of implementing Industry 4.0 concept solutions for underground mining. The analysis was performed with a tabular descriptive method, based on the conducted mining documentation, own observations, surveys and literature research. The indicated limitations and recommendations developed can serve as a guide to further scientific research and implementations in this area.
\end{abstract}

Keywords: analysis, coal mine, industry 4.0, mining machine and devices, new technology 